Article

\title{
Analysis and Assessment of the Building Life Cycle. Indicators and Tools for the Early Design Stage
}

\author{
Roberto Giordano*(D), Federica Gallina and Benedetta Quaglio \\ Department of Architecture and Design, Politecnico di Torino, 10125 Torino, Italy; \\ federica.gallina037@gmail.com (F.G.); benedetta.quaglio@studenti.polito.it (B.Q.) \\ * Correspondence: roberto.giordano@polito.it; Tel.: +39-011-090-4341
}

Citation: Giordano, R.; Gallina, F.; Quaglio, B. Analysis and Assessment of the Building Life Cycle. Indicators and Tools for the Early Design Stage. Sustainability 2021, 13, 6467. https:// doi.org/10.3390/su13116467

Academic Editor: Andrea Pezzuolo

Received: 30 December 2020

Accepted: 28 May 2021

Published: 7 June 2021

Publisher's Note: MDPI stays neutral with regard to jurisdictional claims in published maps and institutional affiliations.

Copyright: (c) 2021 by the authors. Licensee MDPI, Basel, Switzerland. This article is an open access article distributed under the terms and conditions of the Creative Commons Attribution (CC BY) license (https:// creativecommons.org/licenses/by/ $4.0 /)$.

\begin{abstract}
Construction is a crucial sector in terms of worldwide environmental impacts. Building material production along with transport and demolition are no exception, because in the last decades, they have constantly increased their carbon dioxide $\left(\mathrm{CO}_{2}\right)$ emissions. Actions and initiatives are therefore important to tackle the relationship between buildings and climate change. Particularly, it is necessary to develop Life Cycle Assessment (LCA) tools useful to calculate the environmental impact of buildings and to make them accessible to designers and stakeholders acting in the building sector. The article aims to contribute to the international debate about environmental assessment indicators for buildings and the simplified LCA based tools. The Embodied Energy (EE) and the Embodied Carbon (EC) have been investigated. The former, related to primary energy content; the latter, associated with the equivalent carbon dioxide emissions. EE and EC have been used as indicators for the development of a calculation tool named EURECA, for assessing the environmental impact of the building over its life cycle, as defined by the EN 15978:2011 standard. The Solar Decathlon Latin America and Caribbean's house designed and built by an international academic team has been an opportunity to check the indicators and the tool's effectiveness.
\end{abstract}

Keywords: Embodied Energy; Embodied Carbon; Life Cycle Assessment of buildings; LCA tools for early design stage; Solar Decathlon

\section{Introduction}

The global construction industry is in full development. Fatih Birol, Director of the International Energy Agency (IEA), in the foreword to the Global Status Report 2017, "Towards a zero-emission, efficient, and resilient buildings and construction sector", describes how over 230 billion square meters of new buildings are expected to be built over the next 40 years [1]. The report confirms that construction activity is energy-intensive. The consumption raised from 119 Exajoule (EJ) in 2010 to around 125 EJ in 2016. Most of the energy resources of fossil origin used to meet energy needs remained almost constant, over the same period, at around $45 \mathrm{EJ}[1,2]$.

The data analysis concerning carbon dioxide emissions gives more complex information. There is a reduction from 9.5 Gigatons $(\mathrm{Gt})$ of $\mathrm{CO}_{2}$ in 2013 to $9.0 \mathrm{Gt}$ in 2016 associated with consumption for thermal and electrical uses, but there is also an increase in emissions associated with building materials manufacturing and transportation. Such increasing passed from $3.1 \mathrm{Gt}$ in 2010 to $3.7 \mathrm{Gt}$ in 2016.

Several publications [3-5] confirmed the importance of investigating the relationships between energy and environmental impacts beyond their building use, including other stages, such as production, construction, and end-of-life as well as the relevance of studying the $\mathrm{CO}_{2}$ emissions associated with building processes [6,7].

In a background, such as the one just outlined, the paper encourages the use of Embodied Energy (EE) and Embodied Carbon (EC) as building Life Cycle Assessment (LCA) indicators; illustrating the outcomes of a research project that led to the development 
of a building LCA tool suited for the early design stage, which can also be used by nonexpert users.

More in detail, the contribution aims to illustrate an open-source calculation tool named EURECA (Eco-Utility for Reduction of Energy and Carbon).

EURECA has been used to assess some of the environmental project requirements of the Solar Decathlon Latin America and the Caribbean competition (2019), in which the authors and Politecnico di Torino were involved as a partner of the Universidad Javeriana de Bogotá (Colombia) and Oxford Brookes University (UK).

EURECA within the Solar Decathlon has been useful in the early design stage to compare possible alternatives among construction materials; the embodied impacts selected are consistent with the requirements of international contest and suitable for being used in Latin American countries, such as Colombia. In addition, the EE and EC of the production, construction, and end-of-life stages have been correlated with the use of stage impacts to assess the mutual ratios.

\section{Embodied Energy and Embodied Carbon as Indicators to Assess the Building Life Cycle}

Europe is pursuing ambitious goals. It has set out directives, laws, standards, and regulations aimed at reducing energy needs and releases into the water, air, and soil; with regard to the whole life cycle of the building [8,9], however, one must be aware these are rules addressed to a limited portion of nations. The International Energy Agency (IEA) recalls that by 2060 more than half of the new buildings will be built in countries that, at least at this time, have not introduced specific requirements to limit energy consumption [10]. Common actions beyond Europe, and some western countries, are therefore necessary to address the climate change challenges according to the approach of acting locally, thinking globally [11,12]. As reported by some papers $[13,14]$ an environmental building assessment should be based on some kinds of indicators, which can be used in different social and economic contexts.

More specifically, when in construction and an LCA study is mentioned, it can be ascribed to two main areas; the first is aimed at studying the performance of the building as a whole; the second aims to evaluate products and components and it also refers to building systems (e.g., wall systems, roof systems, etc.). This distinction is also reflected in some mandatory regulations $[15,16]$, e.g., the Swiss Minergie ${ }^{\circledR}$ certification system, and technical standards $[17,18]$. This paper is mainly devoted to exploring the first area, with the understanding that in a context such as the one described, a traditional LCA study may be difficult to apply [19]; furthermore, the use of environmental certifications, such as Environmental Product Declarations (EPDs), seems intended for a limited number of projects, buildings, and countries [20].

It is otherwise evident of the need to share common indicators, potentially adaptable to all, and applicable at different levels according to Nation's development. An example are the key actions proposed by the Global Alliance for Buildings and Construction (GABC) Work Areas; these actions include:

1. Raising people's awareness of non-renewable energy consumption and climate change.

2. The improvement of the energy performance of existing buildings.

3. The design of new zero-emission buildings in the (operational) use stage.

4. The improvement of energy management of all buildings

5. The reduction of carbon dioxide emissions associated with energy resources needs for air conditioning, lighting, and domestic hot water production in buildings.

6. The reduction of the energy needs of household appliances.

7. The reduction of Embodied Energy and Embodied Carbon in buildings.

With particular reference to point 7 of the GABC roadmap, the priority is to reduce the primary energy content, as well as the equivalent carbon dioxide emissions $\left(\mathrm{CO}_{2}\right.$ eq. $)$, associated with the building materials, components, and services over their life cycle. 
This means a transition from an all-encompassing assessment approach derived from a traditional LCA study, to one that considers two categories of effects. It is a simplification, but it should be seen as an opportunity to extend the applicability of methods and tools for assessing the building life cycle [20-23]. In addition, these indicators are relatively easy to interpret. One indicator is related to the depletion of energy resources. The other one estimates the greenhouse gases impact.

The EN 15978:2011 [18]—Sustainability of construction works. Assessment of environmental performance of buildings. This standard focuses on setting out the methodology for $\mathrm{EE}$ and EC building accounting. It provides four macro stages of the building life: product, construction process, use, end-of-life, with an optional study concerning the post-use scenario (potential benefits and loads), as shown in Figure 1.

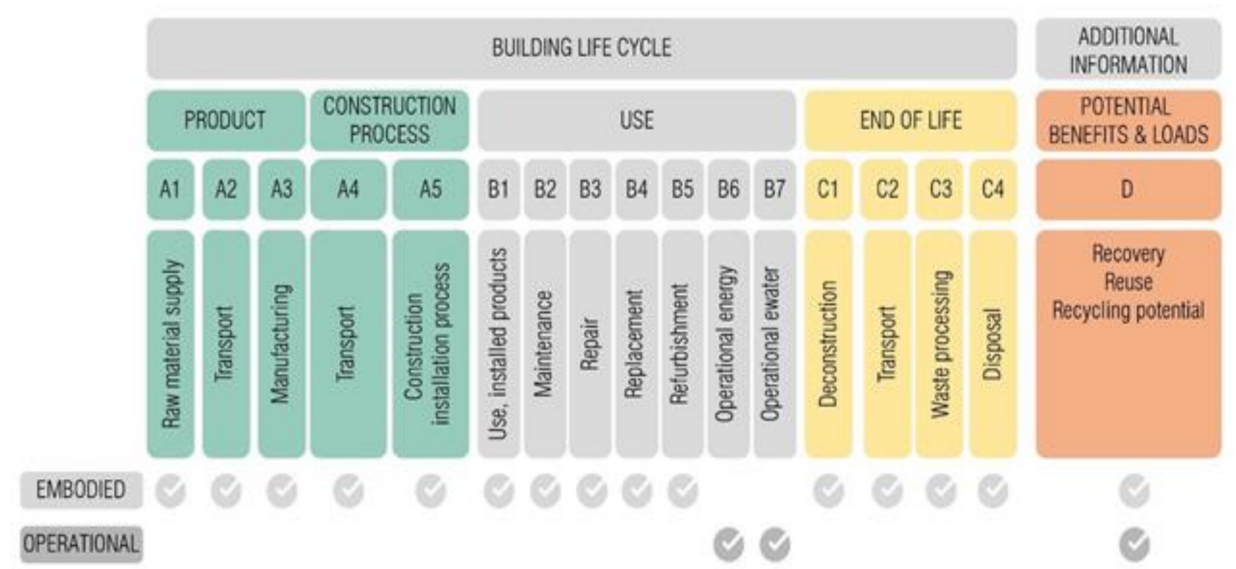

Figure 1. Building Life cycle stages considered in EN 15978:2011. The embodied impacts (EE and EC) are those included by the standard. Operational Energy and Carbon are considered as complementary.

The International Energy Agency in Buildings and Communities Program [24] worked for about six years specifically on the definition and the assessment of the building Embodied Energy and Carbon, involving experts from 15 countries. Precisely:

- $\quad$ Embodied Energy (EE-MJ) corresponds to the demand for primary energy resources.

- Embodied Greenhouse Gases emissions (EG-kg $\mathrm{CO}_{2} \mathrm{eq}$ ), or more simply stated Embodied Carbon, is intended as the weighted sum of the emissions that contribute to the greenhouse effect.

The work carried out by one of the subtasks was also aimed to identify the components that make up each indicator. The task has distinguished: EE from renewable resources; EE from non-renewable resources; EC associated with production processes; EC associated with the extraction and transformation of non-renewable energy resources; and EC stored in materials (mainly wood-based). See Figure 2.

Figure 2 shows also the two main components featuring energy and emission related, named direct and indirect. Direct energy and direct emissions are imputable to a measurable consumption and release of the production system. Indirect energy and indirect emissions are the results of transportation and production of energy and emissions matched to primary and secondary energy resources. In the case of EC calculation, for wood and wood-based materials, a negative value can occur when the carbon embedded in the plant is higher than the $\mathrm{CO}_{2}$ emitted during the other life cycle stages.

The importance of EC as an indicator able to assess the greenhouse gases effect contribution of products and buildings, is also recommended in some publications [5,25]. In combination with EE, EC is a useful indicator to identify offsetting strategies, such as planting trees that absorb carbon in the course of their growth, as confirmed by a study over 150 different regulations and rating schemes for reducing EC [26]. The study concludes that setting carbon limits and compensating for the remaining emissions are effective actions for building decarbonization. 


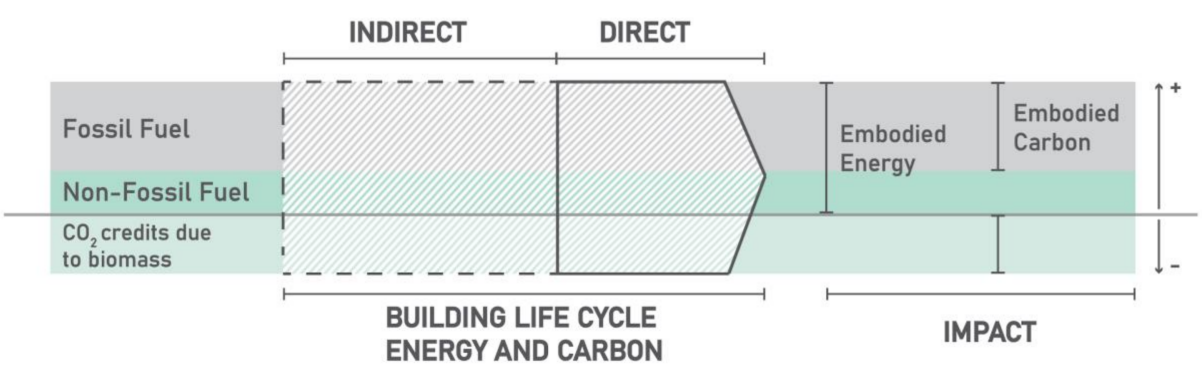

Figure 2. The relationship between Embodied Energy (EE) and Embodied Carbon (EC), according to their energy resources (fossil and non-fossil) and their components (direct and indirect) accounted over the building life cycle. The negative (-) EC value is due to the $\mathrm{CO}_{2}$ credits absorbed by plants in the growth and it can be ascribed to wood and wood-based materials. The positive (+) EC value is correlated to fossil fuels use. Finally, there is not an EC value for no fossil fuels since they have no $\mathrm{CO}_{2}$ and other greenhouse gases emissions.

To better understand the increasing importance of EE and EC indicators, it worth recalling the before mentioned Swiss Minergie ${ }^{\circledR}$ certification. In particular the SIA 2032: 2020 [15] is the technical reference that details how EE and EC must be calculated; besides, it sets: a limit on the primary energy content-EE—of a building (depending on its use); the building life span (set at 50 years); and the normalization methodology that ranks EE according to the building spaces (distinguishing EE for heated spaces and EE for unheated spaces).

Finally, the usefulness of the embodied indicators can be also found in the correlation with other energy and environmental indicators used to assess the use stage of a building. A correlation can be traced between EE and Operational Energy (OE) and EC and Operational Carbon (OC) $[3,4,27,28]$. OE and OC are indicators correlated to the Nearly Zero Energy Building Directive [8].

As it was set out in the EN 15978: 2011, EE and EC measure the energy and environmental performance of most building life cycle stages, except the operational (Figure 2) but - embodied and operational—both accounting for the primary energy contents and the carbon dioxide equivalents emissions. Furthermore, EE and OE, as well as EC and $\mathrm{OC}$ can share the same units (MJ or $\mathrm{kWh}$ and $\mathrm{kgCO}_{2}$ eq.). Therefore, through a normalization process-which takes into account the square meters of heated (and/or unheated) floor area and the expected number of years of the building - it is possible to sum-up the different items and gets an overall building assessment.

The Building Energy Demand (BED) can be calculated as follows:

$$
\mathrm{BED}=\mathrm{OE}+\mathrm{EE}_{\mathrm{P}}+\mathrm{EE}_{\mathrm{C}}+\mathrm{EE}_{\mathrm{U}}+\mathrm{EE}_{\mathrm{EOL}}[\mathrm{MJ}]
$$

where $\mathrm{OE}$ is the Operational Energy; $\mathrm{EE}_{\mathrm{P}}$ is the Production Embodied Energy, also known as Initial Embodied Energy; $\mathrm{EE}_{\mathrm{C}}$ is the Construction Embodied Energy, which includes the Transport Embodied Energy; $\mathrm{EE}_{\mathrm{U}}$ is the Use Embodied Energy, which includes the Recurring Embodied Energy; and $\mathrm{EE}_{\mathrm{EOL}}$ is the End-of-Life Embodied Energy.

Similarly, the Building Carbon Demand (BCD) can be determinate as:

$$
\mathrm{BEC}=\mathrm{OC}+\mathrm{EC}_{\mathrm{P}}+\mathrm{EC}_{\mathrm{C}}+\mathrm{EC}_{\mathrm{U}}+\mathrm{EC}_{\mathrm{EOL}}\left[\mathrm{kg} \mathrm{CO}_{2} \text { eq. }\right]
$$

where $\mathrm{OC}$ is the Operational Carbon; $\mathrm{EC}_{\mathrm{P}}$ is the Production Embodied Carbon, also known as Initial Embodied Carbon; $\mathrm{EC}_{\mathrm{C}}$ is the Construction Embodied Carbon, which includes the Transport Embodied Carbon; $\mathrm{EC}_{\mathrm{U}}$ is the Use Embodied Carbon, which includes the Recurring Embodied Carbon; and $\mathrm{EC}_{\mathrm{EOL}}$ is the End-of-Life Embodied Carbon.

\section{EURECA a Tool for the Building Life Cycle Assessment}

As described, EE and EC are indicators for which there are international attention and a shared interest. However, it cannot be overlooked that their calculation requires 
suitable methods and tools. EE and EC need to be assessed in a timeframe consistent with the design process, starting with the early design stage.

Theoretically, the building embodied impact might be determined through the ISO EN 14040:2006 [29]; nonetheless, an LCA based on this standard involves a high level of complexity [30-32]. As pointed out by some authors [19,33-35] a building LCA is rather complicated and is mostly carried out in the final design stage, when it is possible to make use of EPDs. R. Marsh et al. [31] highlights the importance of some simplifications. They state simplifications are a way to get started with the environmental assessment of a building that would otherwise be difficult to implement.

A more detailed analysis based on EPDs, usually related to the manufacturing of a specific material, is more suitable for the final design when manufacturers are involved and architects no longer work with materials taken from general specifications.

Particularly for designers, in the early design stage, is necessary to use simplified LCA, based on indicators that can be understood and easily interpreted [31]. Such an approach should aim at providing similar results as a detailed LCA, but with a significant reduction in expenses and time used.

Additionally, the LCA at the early design stage of the building design is mainly aimed at understanding whether a building will meet thresholds (e.g., Minergie ${ }^{\circledR}$ ), or to determine which materials may have a greater environmental impact in the building life cycle. The early design refers also mostly to non-commercial materials and the assessment needs generic databases.

The importance to assess environmental impacts at an early stage of building design means that appropriate tools must be used. Several tools have been or are being developed [32,36,37], also with Building Information Modelling (BIM) [38,39]; these are usually time-consuming and suitable for specialized design teams. For less skilled teams, simplified analysis and evaluation tools are needed [31].

Some authors [36] have proposed classification with regards to construction sector:

1. Generic LCA tools;

2. Spreadsheet-based tools;

3. Component catalogues;

4. CAD integrated.

For each typology analysed, the following aspects have been considered: (A) which calculation models and software are available (on-line and/or off-line); (B) the indicators used for the assessment; (C) the country where they were developed; and (D) whether they present functionalities that can be integrated into 3D computer-aided design.

The first type-Generic LCA tools - has been developed for individual LCA products or processes (usually referring to ISO EN 14040: 2006 standard). It is therefore not particularly suitable for a building assessment since it requires a long time to process data.

For tools belonging to the second type-Spreadsheet-based tools-the embodied calculation is given by multiplying the environmental impacts $\left(\mathrm{MJ} / \mathrm{kg}\right.$ or $\mathrm{CO}_{2} / \mathrm{kg}$ ) associated with material-specific weight by the total amount of material itself used in the building. The third type-Component catalogues-refers to online collections able to calculate the embodied impact of elements (e.g., interior wall construction) or sub-elements using as a unit the square meter of the analysed surface; these two types require short processing times and the accounting methods for the embodied impacts can be easily learned by users even if they are not very LCA experienced. Some tools, however, do not allow users to characterize the building layer structures since they cannot implement the available database $[38,39]$.

The fourth type-CAD integrated — involves a combination of design and evaluation tools, also using BIM and Rhino ${ }^{\circledR}$. While recognizing their interesting potential, these tools require users with advanced IT skills, and the level of complexity is suitable for large projects, since for small projects, they are usually not employed.

Finally, it is also worth mentioning the Level(s) initiative, launched within the European Union circular economy rules and framework [40]. Level(s) can be assumed as a new 
European approach to assess and report on the sustainability performance of buildings, throughout the full life cycle of the building. Available reports describe and classify current LCA tools and databases for buildings. There is a good availability of opportunities from the USA, Canada, Australia, and some European countries; in particular, France, Germany, and the United Kingdom, while Italy, Portugal, Greece, and most eastern European countries are not present in the reports. There are also few data on the Latin American and African continents.

From the interpretation of the available information, there would seem to be the conditions for further developments of LCA or LCA based tools, especially if they can be used in different geographical scenarios through data that can be collected and processed by users.

The EURECA tool, here presented, can be included in the scientific background described above.

EURECA means Eco Utility for Reduction of Energy and Carbon and is aimed at developing a tool for designers, not LCA specialists, consistent with the standard EN 15978: 2011. EURECA accounts for the embodied impact of a building and its construction systems (e.g., wall systems, roof systems, partitions, etc.).

Since the current international regulatory system (e.g., the European Directives) does not include any mandatory requirements for the verification of EE and EC indicators, the model provides a default rating system based on the Swiss Minergie ${ }^{\circledR}$ standard (with the certifications class " $\mathrm{A}$ " and class "ECO"). However, the tool is flexible as it allows the user to set which parts of the building to analyse as well as to choose the years of the building life cycle.

The tool development started in the early 2000s with the introduction of an excel spreadsheet intended to assess the environmental performances of a selected number of building life cycle stages.

Over the years, the spreadsheet has been gradually improved, implementing algorithms and developing a building materials database [41]. The current version of the tool was completed in 2019. In June, the testing phase began, applying the tool to several building models featured with different spaces (heated and unheated), materials, and uses. From May up to September 2019, the calculation model was tested for a selected number of case studies.

Consistent with the criteria set by the Swiss standard, EE and EC calculations are divided according to the building spaces. Similarly, with the Minergie ${ }^{\circledR}$ standard, EURECA is also applicable to different uses (e.g., housing, office, etc.), matching the correspondent certification categories and it is also suitable for assessing the impacts of technological retrofit of existing buildings.

Consistent with the classification provided by Hollberg and Ruth [36], EURECA can be considered as a spreadsheet-based tool with a user-integrated database, both working off-line. It must be seen as an open-source tool together with an entry-level database of materials available to users who apply for it.

For the embodied impact assessment, the tool uses a methodology defined as "progressive". EE and EC account starts with the materials, then the tool assesses the building systems, made-up by the different materials, finally, EURECA gets an EE and EC assessment of the whole building (considered as the sum of the building systems and the building services).

The tool is organized by sections to be sequentially filled in: building general data; building systems (divided into systems enclosing the heated spaces and the unheated spaces); windows and doors (also divided according to the spaces they enclose); airconditioning, energy, and hot water equipment; transportations; disposal scenarios. Figure 3 shows how results are available to EURECA users. 


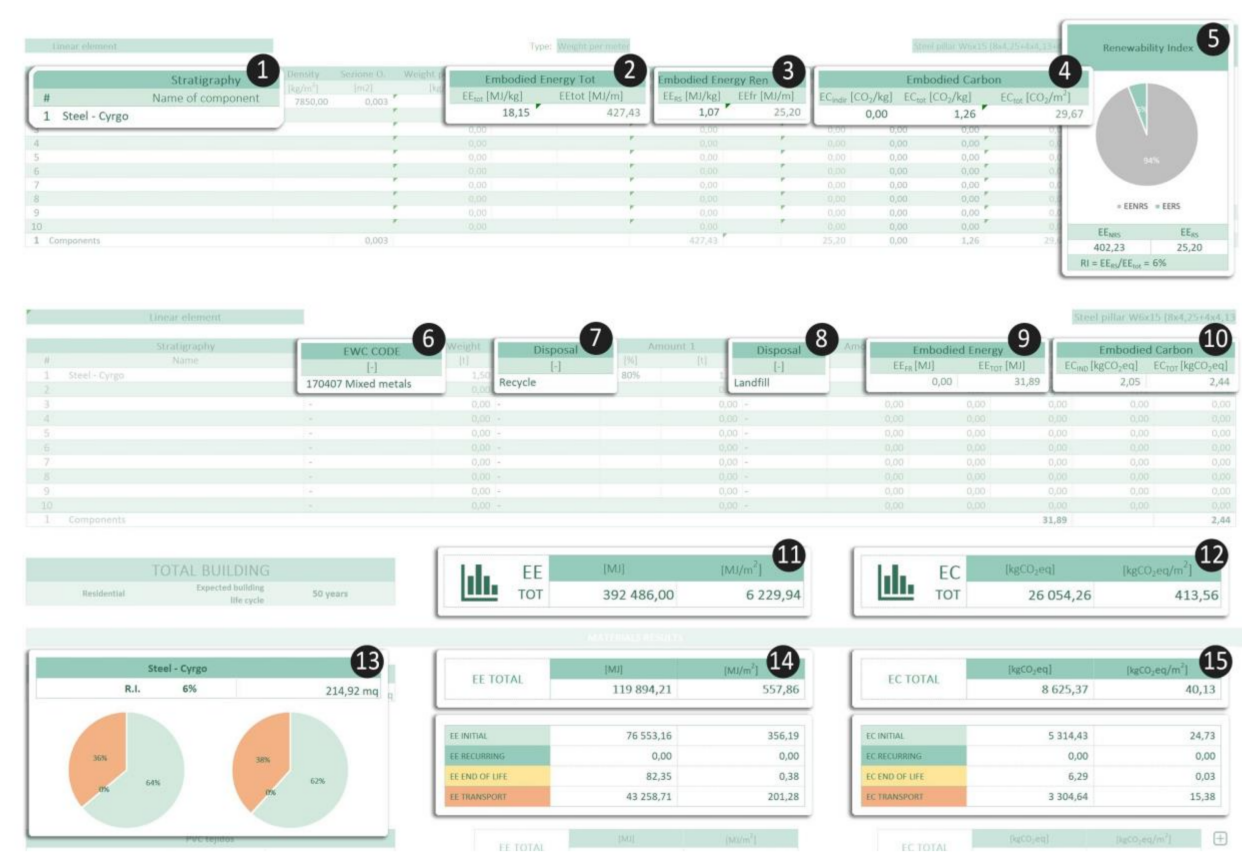

Figure 3. The figure shows the EURECA main results: numbers 1 to 5 refer to EE, EC, and RI of the material, or the building system; numbers 6 to 10 refer to EE and EC of the materials matched to the EU waste code; numbers 11 to 15 refer to EE, EC calculated for the building as a whole.

Each section is made of manual compilation, with data taken from the building geometry and from its technological features, and others that are automatically filled in, using algorithms [42].

In particular, looking at Figure 3, the circled numbers from 1 to 15 display the following data:

- Building systems sheet (1-5); the sheet reports EE and EC values encompassing the production, the construction, and the use, with particular reference to the replacement of the materials $(2,3$, and 4$)$; the sheet accounts for the embodied impact due to the materials stratigraphy (e.g., wall system, floor system, etc.) or a to a single element (e.g., a column or a beam) (1). It is also available the Renewability Index (R.I.) of the analysed building system (5).

- End of life sheet $(6-10) ; \mathrm{EE}$ and EC $(9,10)$ are calculated matching the materials to the corresponding European waste code (6); can be chosen one or two possible disposal options $(7,8)$; the sheet reports also EE and EC values of the avoided impacts for wastes reused or recycled.

- Results sheet (11-15); EE and EC values are referred to the whole building $(11,12)$; the sheet reports even EE and EC according to the considered building stages (production, recurring-replacement, end of life, transport mainly matched to construction process) $(14,15)$ and, finally, it shows Building Renewability Index (13), given dividing EE from renewable resources by the total embodied.

The tool also provides a summary report displaying the following results: (1) Total building Embodied Energy [MJ]; (2) Total building Embodied Carbon ( $\left.\mathrm{kgCO}_{2} \mathrm{eq}\right)$; (3) Annual Embodied Energy (kWh/m²/year); and (4) Renewability Index-R.I. (\%).

Although many LCA and LCA based tools have been developed to assess the embodied impact of a building over its life cycle, EURECA features cannot be easily found in other tools. To make more understandable the achievements, to those with a general LCA knowledge, the tool focuses on some indicators. The database is user-integratable, making it fit to be used in different geographical locations. The filling in of the spreadsheetbased tool is done starting from the materials making-up the building systems. A partially embodied impact is immediately available, this way designers can replace materials at 
any time. Further, the tool—according to the IEA's methodology—provides an overall EE value and a disaggregated EE. Particularly, EURECA makes a distinction between EE from non-renewable resources and EE from renewable resources, allowing the valuation of the mentioned Renewability Index. Such distinction enables the designer to analyse the EE according to the resources used to manufacture the materials.

Finally, the avoided impacts calculation can be assumed as energy and environmental benefits beyond the LCA system boundary. This means that EURECA accounts for the advantages given by recycling and reuse scenarios.

\section{The PEI Maquina Verde's House Life Cycle Assessment through Embodied Energy and Carbon}

An opportunity for testing the EURECA tool was the PEI Maquina Verde's house. The house was designed and built by a team of academics, students, sponsors, and some experts as part of the International Solar Decathlon Latin America and Caribbean competition [43], which took place in Colombia (Cali) in December 2019. See Figures 4 and 5.

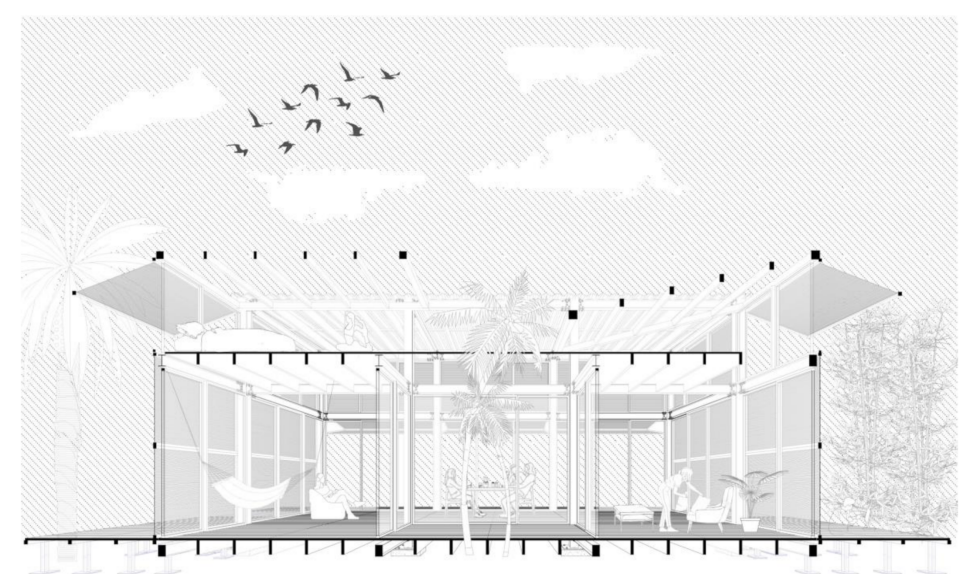

Figure 4. PEI Maquina Verde's House render (source: Federica Gallina, Benedetta Quaglio).

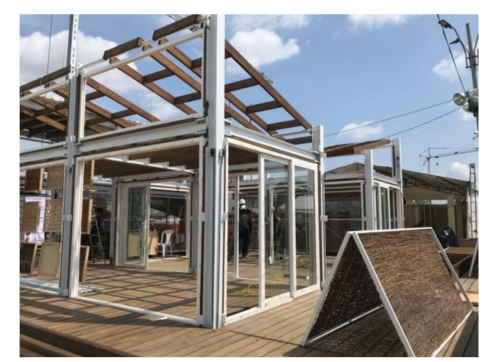

(a)

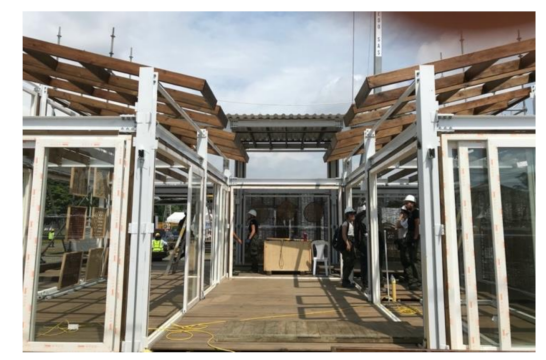

(b)

Figure 5. The PEI Maquina Verde's House construction: (a) on the left the floor and the roof wood beam installation; on the right corner the shading device before the installation, it has made up with vegetal texture installed above a metal frame; (b) the PVC windows installation over the steel structure, the window-to-wall ratio is $80 \%$.

The Pontificia Universidad Javeriana de Bogotá coordinated the context activities, with Politecnico di Torino's contribution and the support of Oxford Brookes University in the initial phases.

The Solar Decathlon is an international competition, which was established in 2002 by the US Department of Energy and is split into continents. It involves international university teams. They design and build residential buildings powered by renewable energy resources and environmentally friendly materials. Starting in 2017, new requirements were introduced, closely connected to the environmental sustainability assessment of the project. In particular, among the evaluation criteria, the competition jury includes one called life 
cycle analysis. More precisely, the requirement focuses on the environmental impact of the housing throughout a study concerning the extraction and transformation of materials, the construction process, the replacement cycles, up to final disposal.

The functional unit introduced by the team in the competition were the annualized building embodied impacts, normalized to the square meter of the conditioned floor area (EE: MJ $/ \mathrm{m}^{2} \times$ year-EC: $\mathrm{kg} \mathrm{CO} 2 \mathrm{eq} / \mathrm{m}^{2} \times$ year). The PEI Maquina Verde's house life span was originally set-out in 50 years and successively in 25 years.

While the project team was choosing the building materials of the different building systems, the EURECA user-integratable database was used to quantify EE and EC.

The next paragraphs describe the building life cycle stages that have been studied and how data have been collected and processed, using the EURECA tool.

\subsection{System Boundaries}

The study has involved the following building stages (see correspondence in Figure 1):

- Production. It included: (1) the raw materials supply; (2) the transport (based on the average value obtained from the databases available to the research team); (3) the production of intermediates products and final products.

- Construction transports. They included the processes for moving materials from off-site production to the on-site (building site).

- Repair and replacement. They included the exchange of materials with an expected life of less than 50 years.

- End-of-life. It included waste transportation and the final disposal scenarios assessment.

With regards to indications given in the EN 15978:2011 standard, the EURECA analysis and assessment also considered the post-demolition stage. Therefore, the impacts that can be avoided through virtuous reuse and recycling processes were quantified. Within the Solar Decathlon competition, the avoided impacts were studied as potential energy and environmental benefits. These benefits go beyond the system boundaries (therefore, they have been considered separately in the study) since they predict what might occur after the building lifespan.

The following processes-instead-have not been taken into account:

- Installation processes, since it is a house designed to be self-built, the energy and environmental impacts are mainly due to the human resources employed, so they are difficult to estimate.

- Deconstruction, for the same reasons as the exclusion criteria used for the installation processes.

Finally, the use/operational stage, as the energy needs and related emissions, have been assessed through other modelling tools and also used in a second part of the evaluation to correlate EE and OE as well as EC and OC.

\subsection{Inventory Analysis}

The collected data were critically reviewed (in terms of content, origin, and processing timeframe) before they were input into the EURECA tool. The opportunity for the designers to implement the database with data provided directly by some team's sponsoring companies has made it possible to work, right from the early design stage, with a large portion of direct data. Other data-indirect data-were evaluated using scientific publications and databases normalized on the energy Colombian mix (e.g., Ecoinvent). Table 1 displays the main materials used for the PEI Maquina Verde's house and the corresponding quantities. 
Table 1. Summary of materials and components included in the inventory analysis. The table shows the total amount of materials used in the PEI Maquina Verde's house. The third column, from the left, describes the quantity of material normalised to the $\mathrm{m}^{2}$ of the construction system it is used in. The fourth column, from the left, describes the quantity of material normalised on the $\mathrm{ml}$ of the structural system it is used in.

\begin{tabular}{|c|c|c|c|}
\hline Materials & $($ tot $t)$ & $\left(\mathrm{kg} / \mathrm{m}^{2}\right)$ & $(\mathrm{kg} / \mathrm{m})$ \\
\hline PVC (roof decking) & 0.78 & 4.90 & \\
\hline PVC (roof decking) & 0.60 & 2.21 (window frame) & 1.26 (studs and mullions) \\
\hline Glass & 2.07 & 20 & \\
\hline Wood (roof system) & 1.10 & $\begin{array}{l}17.36 \text { (panelling) } \\
9.58 \text { (decking) }\end{array}$ & \\
\hline Wood (wall system) & 0.03 & 0.73 & \\
\hline Wood (frame work) & 0.77 & & $1.22 \div 2.97$ \\
\hline $\begin{array}{l}\text { Palm based natural fibres } \\
\text { (shading devices) }\end{array}$ & 0.13 & 0.60 & \\
\hline Steel structure & 3.87 & & 15.70 \\
\hline
\end{tabular}

For most of the data, a review approach was adopted, by a comparison of multiple resources, to ensure good data accuracy. In particular, an analytical study has been carried out comparing direct data (from EPDs and audits with material manufacturers) and indirect data (from databases available to the research team). An example of a data sheet for one of the products used in the PEI Maquina Verde's house is shown in Figure 6.

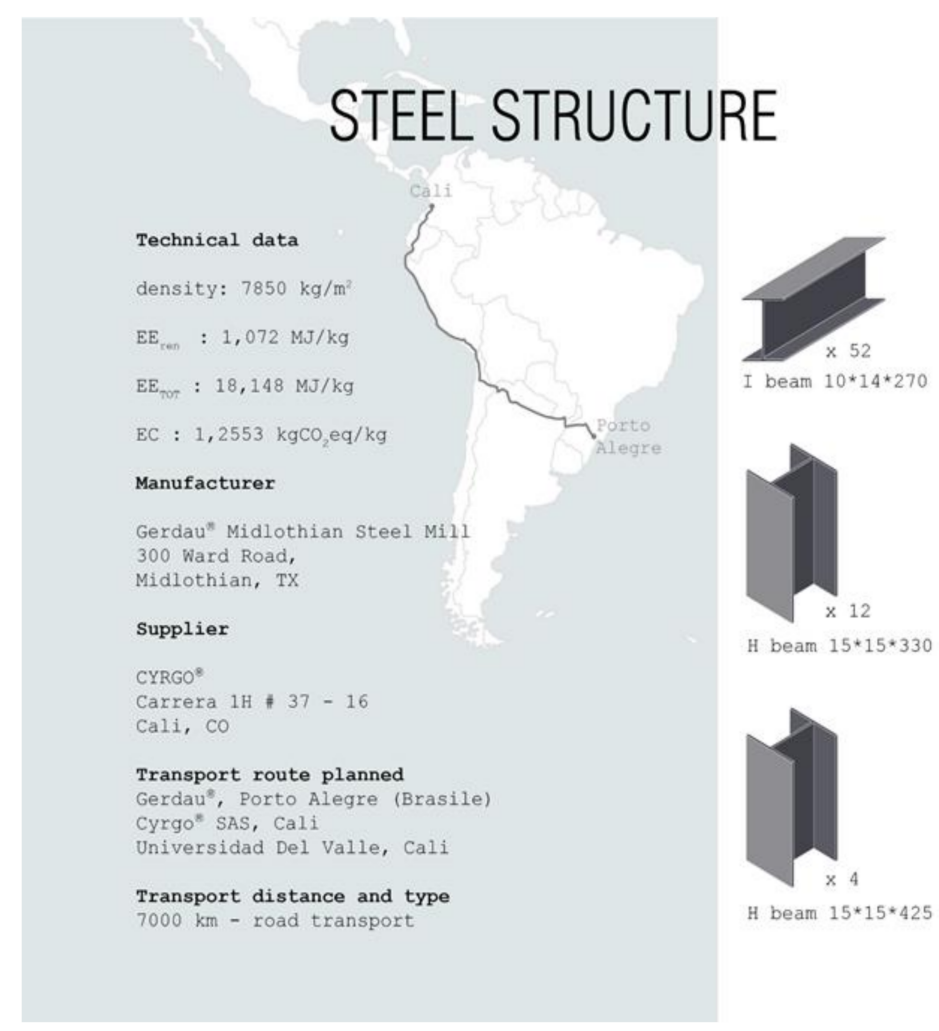

Figure 6. Data collection sheet for materials used in the PEI Maquina Verde's House. The example refers to the steel structure. In the sheet are reported the main material features (technical data), information about the production site (manufacturer) and the distribution site (supplier), route, distance, and type of transport from manufacturer to supplier(s), from the supplier(s) to construction site (transport planned route and transport distance and type). (Source: Federica Gallina, Benedetta Quaglio). 


\subsection{Impact Assessment and Results}

The EURECA tool was used to determine EE and EC values of the PEI Maquina Verde's house, first in disaggregated form and then in aggregated one. Table 2 summarizes the main results.

Table 2. Impact assessment summary: Embodied Energy (MJ) and Embodied Carbon ( $\left.\mathrm{kgCO}_{2} \mathrm{eq}\right)$ for the PEI Maquina Verde's House life cycle. Capital letters (from A to D) refer to the EN 15978:2011 standard stages (see Figure 1).

\begin{tabular}{|c|c|c|c|c|c|c|}
\hline & TOTAL & $\begin{array}{l}\text { Production } \\
\text { (A1, A2, A3) }\end{array}$ & $\begin{array}{c}\text { Use } \\
\text { (B1, B2, B3, B4, B5) }\end{array}$ & $\begin{array}{l}\text { End-of-Life } \\
\text { (C2, C3, C4) }\end{array}$ & $\begin{array}{l}\text { Transport } \\
\text { (A4, C2) }\end{array}$ & $\begin{array}{l}\text { Avoided Impacts } \\
\text { (D) }\end{array}$ \\
\hline EE & $\begin{array}{l}392,486.00 \mathrm{MJ} \\
6229.94 \mathrm{MJ} / \mathrm{m}^{2}\end{array}$ & 195,122.33 MJ & 63,177.45 MJ & 196.23 MJ & 133,989.99 MJ & $-190,425.93 \mathrm{MJ}$ \\
\hline EC & $\begin{array}{l}26,054.26 \mathrm{kgCO}_{2} \mathrm{eq} \\
413.56 \mathrm{kgCO}{ }_{2} \mathrm{eq} / \mathrm{m}^{2}\end{array}$ & $10,752.90 \mathrm{kgCO}_{2} \mathrm{eq}$ & $5049.68 \mathrm{kgCO}_{2} \mathrm{eq}$ & $14.99 \mathrm{kgCO}_{2} \mathrm{eq}$ & $10,236.69 \mathrm{kgCO}_{2} \mathrm{eq}$ & $-8329.03 \mathrm{kgCO}_{2} \mathrm{eq}$ \\
\hline
\end{tabular}

Total EE amounts to $6229.94 \mathrm{MJ} / \mathrm{m}^{2}$ of floor area. Such a value corresponds to $34.61 \mathrm{kWh} / \mathrm{m}^{2} \times$ year, normalized over 50 years of the building life. The $50 \%$ of the primary energy content is due to the production stage of the building systems; $34 \%$ is related to transport; and $16 \%$ to the replacement of materials (a relatively high value due to the presence of natural materials with a limited lifespan, in particular, the vegetal shading device); due to boundaries considered, the EE associated with demolition stage is negligible. In the PEI Maquina Verde's, PVC was found to be one of the most impactful materials (EE: 1149. $72 \mathrm{MJ} / \mathrm{m}^{2}$ ).

Total EC corresponds to $413.56 \mathrm{kgCO} 2 \mathrm{eq} / \mathrm{m}^{2}$ of floor area. In the EC assessment, the most significant percentage of emissions is attributable to the production $(41 \%)$ and the transport stage (39\%). The $20 \%$ of emissions refer to replacement processes of materials over the 50-year life cycle.

As pointed out above, EURECA allows the assessment of avoided impacts by analysing the expected reuse and recycling scenarios. The end-of-life scenario shows for steel, PVC, glass, and wood a recycling percentage of $80 \%$, with the hypothesis of accessing the respective recycling plants in a $30 \mathrm{~km}$ radius. The potential avoided energy needs and a potential avoided $\mathrm{CO}_{2}$ emission due to reuse and recycling processes are, respectively, $3022.63 \mathrm{MJ} / \mathrm{m}^{2}$ and $132,21 \mathrm{kgCO} 2 \mathrm{eq} / \mathrm{m}^{2}$.

\section{Discussion}

In general, the findings concerning the PEI Maquina Verde's House confirm some scientific studies: the production stage among the stages encompassed by the EN 15978:2011 is the most relevant $[3,25,44,45]$. Within the production, the impact of PVC is remarkable as it is one of the materials chosen with a high EE value and a Renewability Index almost equal to zero. Its particularly high impact is also due to the fact that PVC was used as the frame of the windows, which account for $80 \%$ (window-to-wall ratio) of the total vertical surface; a critical issue that was identified during the early design stage and led the team to consider alternative options; however, it was decided not to replace PVC because, if compared to wood or aluminium-wood window frames, it was the lightest technology and therefore easier to install in the construction site. Nevertheless, as previously highlighted, PVC can recover some of its EE if it is properly recycled, and the team statement was to enhance (prioritizing the reuse scenario) the most impactful materials at the building end-of-life.

Of some interest is the transport embodied impacts. In Colombia, as well as in many Latin American countries, the transportation system is mainly by road; there are few connections by train and also domestic navigation is possible in very few parts of the country. Indeed, the embodied impact of a manufacturing system does not change significantly among countries [46], especially if energy resources used as input are derived from fossil fuels. When, instead, the embodied impact affects the type of vehicle and its load capacity, it can lead to significant variability. The rather high embodied impact of 
the analysed building could be less relevant if the transportation took place with electrical vehicles or if the quantities of materials transported were optimized, e.g., via goods train.

The option of calculating the building cycle stages separately (as required in EN 15978: 2011) is therefore essential since a change from one transport system to another might significantly change its magnitude.

Another topic to be discussed concerns the comparison between the embodied impacts and the operational impacts.

As mentioned (in paragraph 2), there is an increasing interest in studying the relationships between embodied and operational impacts. For assessing OE and OC, the software EDGE was used.

Considering the Solar Decathlon site climate, the main contribution to OE is given by the cooling energy $\left(27 \mathrm{kWh} / \mathrm{m}^{2} \times\right.$ year $)$ to which must be added a value of $18 \mathrm{kWh} / \mathrm{m}^{2}$ $\times$ year given by the electric consumption of lightings, home appliances, and fan energy. The OC value was calculated using specific emission factors that take into account, both electricity taken from the Colombian grid and electricity produced onsite $\left(1327 \mathrm{~kg} \mathrm{CO} / \mathrm{m}^{2}\right.$ $\times$ year).

For the PEI Maquina Verde House, the comparison between OE and EE and between OC and EC shows that the operational impacts are still higher than the embodied impacts (OE 56\%; EE 44\%-OC 59\%, EC 41\%). This is mainly due to the building estimated lifespan. When the lifespan was considered shorter: 25 years, the normalized EE value passed from 34.61 to $69.22 \mathrm{kWh} / \mathrm{m}^{2} \times$ year with a higher value than that $\mathrm{OE}$. A reduction of the building lifespan also has an effect on EC impact. With a life cycle assumed to be 25 years, $\mathrm{EC}$ rises from $8.78 \mathrm{~kg} \mathrm{CO} / \mathrm{m}^{2} \times$ year to almost $17 \mathrm{~kg} \mathrm{CO} 2 / \mathrm{m}^{2} \times$ year. The comparison between EC and OC shows still a higher value of the operational stage, but this is due to the biomass materials (used in particular for the building shading devices) which absorbs $\mathrm{CO}_{2}$ during plant growth and which remains stocked in products over the building life cycle. It is likely that if the building shading devices were made with more traditional materials (e.g., PVC or aluminium louvres), the $\mathrm{CO}_{2}$. would be higher with a substantial identity with $\mathrm{EE}$ and $\mathrm{OE}$ performances.

As highlighted, a further embodied impact assessment was focused on the building end of life. The EURECA tool makes it possible to determine the avoided impacts values given by reuse and recycling scenarios. In compliance with the EN 15978:2011 standard, they cannot be used in the embodied accounts, they must be reported separately. The potential reuse and recycling were considered as independent indicators within the Solar Decathlon aimed at compensating for the high embodied impact of some materials.

In the PEI Maquina Verde's House, the avoided impacts values almost correspond to production EE and EC values. Such results are relatively important since they mean that a high number of materials were selected to be enhanced as secondary raw materials after their disposal.

It was also used to determine the impact related to the use of building systems laid down through reverse assembling procedures and-as a consequence-elements fit for a selective demolition. The selective demolition was considered crucial since it was set out to minimize the waste at the competition end.

Due to the competition timeframe conditions of Solar Decathlon, it was not possible to carry out an LCA in depth. Nevertheless, it was possible to make some comparisons between generic data, i.e., information from bibliographic sources and databases, and documentation provided by enterprises and suppliers. Section 4.2 described the methodology of inventory analysis, carried out by comparing indirect and direct data. Working in close cooperation with the manufacturers of materials used in PEI Maquina Verde's House has allowed us to check the deviation between direct and indirect EE and EC values. According to the competition guidelines, the EE and EC values were accounted for by EURECA with direct data only if available through EPDs.

The lowest difference was found when comparing EE and EC of PVC and glass. The $\mathrm{EE}$ from indirect data is $3 \%$ higher than the $\mathrm{EE}$ value from direct data; the $\mathrm{EC}$ from indirect 
data is $4 \%$ higher than the EC value from direct data. In this comparison, direct data were obtained by EPD reports. For PVC and glass, the difference is related to the electricity used in the energy manufacturing processes. The EPDs analysis shows that for the two materials, a higher share of renewable energy from hydroelectric and photovoltaic sources is used for electricity production. This change leads to a reduction in EE and EC, both attributed to the lack of extraction and transformation of resources from fossil sources.

A wider percentage difference has been observed when EE and EC values for wood have been analysed. EPDs were not available for timber, so some information was gathered from audits carried out with the enterprises. Of particular interest was the comparison concerning the carbon sequestration by plants in their lifecycle. The quantification was based on different methods of analysis and evaluation. Direct data (i.e., data provided by companies) report higher amounts of carbon absorbed during the life of the plant, about $7 \%$ more than the value calculated using indirect data. Due to the lack of EPDs, it was decided to fill EURECA with values derived from the design team's database, for the clarity of the calculation method based on allometric biomass equations.

Finally, for the shading device, a comparison between direct and indirect data was not possible. Palm-based natural fibres were harvested and processed by manual techniques; therefore, $\mathrm{EE}$ and $\mathrm{EC}$ were determined only once with indirect data, by counting the absorbed carbon content according to the weight of the natural fibres, and later on, by adding in the account the transport processes from the initial transformation site to the construction one.

Although the team worked with heterogeneous data, the comparison between direct and direct data shows higher values in the range between +3 and $+7 \%$ in $\mathrm{EE}$ and $\mathrm{EC}$ calculated with indirect data. This means the life cycle impact of most building systems used in the PEI Maquina Verde's house is higher when average data from databases are used in the assessment.

\section{Conclusions}

The research carried out shows the utility of some indicators derived from an LCA study that can be used and interpreted by designers in choosing the most environmentally friendly materials or scenario.

The paper deals with the importance of using tools organized according to different levels of complexity, the ability to assess embodied impacts in the early design stage, and further, in general, to assist several stakeholders acting in the building process. Furthermore, those adaptable tools able to assess EE and EC in different geographical contexts are also appreciated.

Particularly the EURECA tool application shows that a simplified building LCA can be achieved accounting for EE and EC, consistent with the EN 15978: 2011 standard. Moreover, in compliance with EN, EURECA sets some boundaries in the analysis process to make the LCA compatible with the design timeframe.

Furthermore, the tool provides an implementation trough a correlation between the EN standard and the Minergie ${ }^{\circledR}$ regulating reference.

Another aspect to be considered, is its feature matching being a largely objective assessment-of those stages from resource extraction to final disposal-with a more subjective assessment, involving potential post-use material scenarios, being used in the building. A quite innovative approach, able to predict what will potentially occur at the building in its end-of-life.

Future developments might include the use of EURECA as a complementary tool to existing building certification systems, especially for those criteria or requirements aimed at assessing the environmental sustainability of construction materials (e.g., LEED $^{\circledR}$ ). In the future, it might be useful to widen the range of EURECA applications, including infrastructures with potential high embodied impacts such as airports, concert halls, or exhibition buildings. 
An aspect to be considered for further development can be traced back to the definition of the maximum and minimum percentage deviations of the EE and EC values accounted for in the early design and later stages.

Another element to be developed is the correlation between environmental and economic indicators. Of some interest is the carbon dioxide equivalent monetization. For many types of stakeholders, this could be an opportunity to evaluate part of the life cycle cost of a building.

Finally, EURECA's capability to calculate the $\mathrm{CO}_{2}$ equivalent emissions of a building can be a useful option in all those cases where the greenhouse effect needs to be compensated by forestation operations.

Author Contributions: The individual contributions of the authors are reported. Conceptualization, R.G.; methodology and investigation, R.G., F.G. and B.Q.; first software design, R.G.; software implementation, F.G. and B.Q.; writing-review and editing, R.G.; data curation, F.G. and B.Q.; supervision, R.G.; funding acquisition, R.G. All authors have read and agreed to the published version of the manuscript.

Funding: This research was funded by Joint Projects for Internationalization of Research, Politecnico di Torino and Compagnia di San Paolo.

Institutional Review Board Statement: Not applicable.

Informed Consent Statement: Not applicable.

Data Availability Statement: Not applicable.

Acknowledgments: The authors would like to thank Angela Duzel and Enrico De Maria for the initial calculation model development and some preliminary research activities. Special thanks go to Carlos Alberto Hernandez Correa for his coordination work on the Solar Decathlon house project. Thanks also to Lorenzo Savio and Monica Muñoz for their support in collecting useful information for the life cycle analysis of the PEI Maquina Verde building.

Conflicts of Interest: The authors declare no conflict of interest.

\section{References}

1. International Energy Agency. Global Status Report 2017. Towards a zero-emission, efficient, and resilient buildings and construction sector. In World Energy Statistics and Balances; IEA/OECD: Paris, France, 2017; Available online: www.iea.org/ statistics (accessed on 30 October 2020).

2. Lucon, O.; Ürge-Vorsatz, D.; Zain Ahmed, A.; Akbari, H.; Bertoldi, P.; Cabeza, L.F.; Eyre, N.; Gadgil, A.; Eyre, N.; Gadgil, A.; et al. Buildings. In Climate Change 2014, Mitigation of Climate Change. Fifth Assessment Report of the Intergovernmental Panel on Climate Change; Cambridge University Press: Cambridge, UK; New York, NY, USA, 2014; Available online: https: //www.ipcc.ch/site/assets/uploads/2018/02/ipcc_wg3_ar5_chapter9.pdf (accessed on 12 December 2020).

3. Benjamin, D.N. Embodied Energy and Design: Making Architecture between Metrics and Narratives; Lars Müller Publishers: Zurich, Switzerland, 2017.

4. Pacheco-Torgal, F.; Faria, J.; Jalali, S. Embodied Energy versus Operational Energy. Showing the Shortcomings of the Energy Performance Building Directive (EPBD). Available online: www.scientific.net/MSF.730-732.587 (accessed on 30 October 2020).

5. Ayaz, E.; Frances, Y. Zero Carbon Isn't Really Zero: Why Embodied Carbon in Materials Can't Be Ignored. Available online: https:/ / www.di.net/articles/zero_carbon/ (accessed on 25 November 2020).

6. International Energy Agency. Global Energy and $\mathrm{CO}_{2}$ Status Report 2018. IEA/OECD. 2019. Available online: https://www. eenews.net/assets/2019/03/26/document_cw_01.pdf (accessed on 25 November 2020).

7. Allen, M.; De Coninck, H.; Dube, O.P.; Hoegh-Guldberg, O.; Jacob, D.; Jiang, K.; Revi, A.; Rogelj, J.; Roy, J.; Shindell, D.; et al. Technical Summary. Global Warming of $1.5^{\circ} \mathrm{C}$. An IPCC Special Report on the Impacts of Global Warming of $1.5^{\circ} \mathrm{C}$ above Pre-Industrial Levels and Related Global Greenhouse Gas Emission Pathways, in the Context of Strengthening the Global Response to the Threat of Climate Change, Sustainable Development, and Efforts to Eradicate Poverty. 2018. Available online: https://www.ipcc.ch/site/assets/uploads/sites/2/2018/12/SR15_TS_High_Res.pdf (accessed on 25 January 2021).

8. European Commission. Directive 2010/31/EU on the Energy Performance of Buildings; European Parliament: Brussels, Belgium, 2010.

9. European Regional Network. LEVEL(S): A Guide to Europe's New Reporting Framework for Sustainable Buildings. Available online: https:/ / ec.europa.eu/environment/eussd/pdf/Level_publication_EN.pdf (accessed on 25 November 2020).

10. International Energy Agency. Energy Technology Perspectives 2017; IEA/OECD: Paris, France, 2017; Available online: www.iea.org/ etp (accessed on 15 November 2020). 
11. Taffese, W.Z.; Abegaz, K.A. Embodied Energy and $\mathrm{CO}_{2}$ Emissions of Widely Used Building Materials: The Ethiopian Context. Buildings 2019, 9, 136. [CrossRef]

12. Nawarathna, A.; Alwan, Z.; Fernando, N.; Gledson, B. Estimating Embodied Carbon emissions of buildings in developing countries: A case study from Sri Lanka. In Proceedings of the 4th International Sustainable Ecological Engineering Design for Society (SEEDS) Conference, Dublin, Ireland, 6-7 September 2018.

13. Kibwami, N.; Tutesigensi, A. Managing Embodied Carbon in Africa trough a Carbon Trading Scheme. In Embodied Carbon in Buildings; Measurement, Management and Mitigation; Springer: Berlin/Heidelberg, Germany, 2018; pp. 367-392. [CrossRef]

14. Pomponi, F.; Medina Campos, L. Embodied and Life Cycle Carbon Assessment of Buildings in Latin America: State-of-the-Art and Future Directions. In Embodied Carbon in Buildings; Measurement, Management and Mitigation; Springer: Berlin/Heidelberg, Germany, 2018; pp. 483-503. [CrossRef]

15. Cahier Technique SIA 2032. L'énergie Grise-Établissement du Bilan Écologique pour la Construction de Bâtiments. 2020. Available online: http:/ / shop.sia.ch/collection\%20des\%20normes/architecte/sia\%202032/f/2020/F/Product (accessed on 25 November 2020).

16. Kuittinen, M. Method for the Whole Life Carbon ASSESSMENT of Buildings. 2019. Available online: https://julkaisut. valtioneuvosto.fi/handle/10024/161796 (accessed on 15 February 2021).

17. European Committee for Standardization. Sustainability of Construction Works_Environmental Product Declarations-Core Rules for the Product Category of Construction Products; EN 15804:2012 + A2:2019; European Committee for Standardization: Brussels, Belgium, 2019.

18. European Committee for Standardization. Sustainability of Construction Works-Assessment of Environmental Performance of BuildingsCalculation Method; EN 15978:2011; European Committee for Standardization: Brussels, Belgium, 2011.

19. Kellenberger, D.; Althaus, H.-J. Relevance of simplifications in LCA of building components. Build. Environ. 2009, 44, 818-825. [CrossRef]

20. Lupíšek, A.; Vaculíková, M.; ManL'ík, Š.; Hodková, J.; Růžil'ka, J. Design Strategies for Low Embodied Carbon and Low Embodied Energy Buildings: Principles and Examples. Energy Procedia 2015, 83, 147-156. [CrossRef]

21. Moncaster, A.; Symons, K. A method and tool for 'cradle to grave' embodied carbon and energy impacts of UK buildings in compliance with the new TC350 standards. Energy Build. 2013, 66, 514-523. [CrossRef]

22. Ekundayo, D.; Babatunde, S.O.; Ekundayo, A.; Perera, S.; Udeaja, C. Life cycle carbon emissions and comparative eval-uation of selected open source UK Embodied Carbon counting tools. Constr. Econ. Build. 2019, 19, 220-242.

23. Pomponi, F.; De Wolf, C.; Moncaster, A. Embodied Carbon in Buildings; Measurement, Management and Mitigation; Springer: Berlin/Heidelberg, Germany, 2018.

24. International Energy Agency in Buildings and Communities Programme. Evaluation of Embodied Energy and $\mathrm{CO}_{2} \mathrm{eq}$ for Building Construction (Annex 57). 2016. Available online: http://www.iea-ebc.org/Data/publications/EBC_Annex_57_Results_ Overview.pdf (accessed on 15 November 2020).

25. Azari, R.; Abbasabadi, N. Embodied energy of buildings: A review of data, methods, challenges, and research trends. Energy Build. 2018, 168, 225-235. [CrossRef]

26. Castro, R.; Terranova, E.; Bruce-Hyrkäs, T.; Pasanen, P. The Embodied Carbon Review. Embodied Carbon Reduction in 100+ Regulations $\mathcal{E}$ Rating Systems Globally; Bionova Ltd.: Helsinki, Finland, 2018; Available online: https://www.oneclicklca.com/wp-content/ uploads/2018/12/Embodied_Carbon_Review_2018.pdf.

27. Giordano, R.; Serra, V.; Demaria, E.; Duzel, A. Embodied Energy Versus Operational Energy in a Nearly Zero Energy Building Case Study. Energy Procedia 2017, 111, 367-376. [CrossRef]

28. Bruce-Hyrkäs, T.; Pasanen, P.; Castro, R. Overview of Whole Building Life-Cycle Assessment for Green Building Certification and Ecodesign through Industry Surveys and Interviews. Procedia CIRP 2018, 69, 178-183. [CrossRef]

29. International Organization for Standardization. Environmental Management_Life Cycle Assessment_Principles and Framework; ISO 14040:2006; ISO/TC 207/CS 5; International Organization for Standardization: Geneva, Switzerland, 2006.

30. Basbagill, J.; Flager, F.; Lepech, M.; Fischer, M. Application of life-cycle assessment to early stage building design for reduced embodied environmental impacts. Build. Environ. 2013, 60, 81-92. [CrossRef]

31. Marsh, R.; Rasmuseen, N.; Birgisdottir, H. Embodied Carbon Tools for Architects and Clients Early in the Design Process. In Embodied Carbon in Buildings; Measurement, Management and Mitigation; Springer: Berlin/Heidelberg, Germany, 2018; pp. 167-190.

32. Lasvaux, S.; Ganter, J. Towards a new generation of building LCA tools adapted to the building design process and to the user needs? In Proceedings of the International Conference on Sustainable Buildings, Construction Products \& Technologies, Gratz, Austria, 25-28 September 2013; pp. 406-417.

33. Soust-Verdaguer, B.; Llatas, C.; García-Martínez, A. Simplification in life cycle assessment of single-family houses: A review of recent developments. Build. Environ. 2016, 103, 215-227. [CrossRef]

34. Hollberg, A.; Kiss, B.; Röck, M.; Soust-Verdaguer, B.; Wiberg, A.H.; Lasvaux, S.; Galimshina, A.; Habert, G. Review of visualising LCA results in the design process of buildings. Build. Environ. 2021, 190, 107530. [CrossRef]

35. Bribián, I.Z.; Usón, A.A.; Scarpellini, S. Life cycle assessment in buildings: State-of-the-art and simplified LCA methodology as a complement for building certification. Build. Environ. 2009, 44, 2510-2520. [CrossRef]

36. Hollberg, A.; Ruth, J. LCA in architectural design—a parametric approach. Int. J. Life Cycle Assess. 2016, 21, 943-960. [CrossRef] 
37. Sartori, T.; Drogemuller, R.; Omrani, S.; Lamari, F. A schematic framework for Life Cycle Assessment (LCA) and Green Building Rating System (GBRS). J. Build. Eng. 2021, 38, 102180. [CrossRef]

38. Naneva, A.; Bonanomi, M.; Hollberg, A.; Habert, G.; Hall, D. Integrated BIM-Based LCA for the Entire Building Process Using an Existing Structure for Cost Estimation in the Swiss Context. Sustainability 2020, 12, 3748. [CrossRef]

39. Obrecht, T.P.; Röck, M.; Hoxha, E.; Passer, A. BIM and LCA Integration: A Systematic Literature Review. Sustainability 2020, 12, 5534. [CrossRef]

40. Level(s) Common Framework. Available online: https://susproc.jrc.ec.europa.eu/product-bureau//product-groups/412/home (accessed on 5 February 2021).

41. Giordano, R. I Prodotti per L'edilizia Sostenibile: La Compatibilità Ambientale dei Materiali nel Processo Edilizio, 1st ed.; Esselibri-Simone: Naples, Italy, 2010.

42. Gallina, F.; Quaglio, B. EURECA: A model for Parametric Analysis and Assessment of the Environmental and Energy Impacts of Buildings over Their Life Cycle. Master's Thesis, Politecnico di Torino, Torino, Italy, 2019.

43. Herrera-Limones, R.; León-Rodríguez, Á.L.; López-Escamilla, Á. Solar Decathlon Latin America and Caribbean: Comfort and the Balance between Passive and Active Design. Sustainability 2019, 11, 3498. [CrossRef]

44. Fregonara, E.; Giordano, R.; Rolando, D.; Tulliani, J.-M. Integrating Environmental and Economic Sustainability in New Building Construction and Retrofits. J. Urban Technol. 2016, 23, 3-28. [CrossRef]

45. Ibn-Mohammed, T.; Greenough, R.; Taylor, S.; Ozawa-Meida, L.; Acquaye, A. Operational vs. embodied emissions in buildingsA review of current trends. Energy Build. 2013, 66, 232-245. [CrossRef]

46. Baldo, G.L.; Marino, M.; Rossi, S. Analisi del Ciclo di Vita LCA; Edizioni Ambiente: Milan, Italy, 2008. 